\title{
Phlyctenular conjunctivitis: a rare association with spinal intramedullary tuberculoma
}

\author{
Aveg Bhandari, ${ }^{1}$ Heena Bhandari, ${ }^{2}$ Rakesh Shukla, ${ }^{1}$ Prithvi Giri ${ }^{1}$
}

${ }^{1}$ Department of Neurology, King George's Medical University, Lucknow, Uttar Pradesh, India ${ }^{2}$ Department of Ophthalmology, King George's Medical

University, Lucknow, Uttar Pradesh, India

\section{Correspondence to}

Professor Rakesh Shukla, rakeshshukla_rakesh@ rediffmail.com

Accepted 17 January 2014
CrossMark

To cite: Bhandari $A$ Bhandari $H$, Shukla $R$, et al. BMJ Case Rep Published online: [please include Day Month Year] doi:10.1136/ bcr-2013-202010

\section{SUMMARY}

We present a case of a 33-year-old woman who presented with phlyctenular conjunctivitis while on treatment for spinal intramedullary tuberculosis. She was treated with topical steroids along with continuation of antitubercular therapy, and improved on this treatment.

\section{BACKGROUND}

We present a case of a 33-year-old woman who presented with phlyctenular conjunctivitis while on treatment for spinal intramedullary tuberculosis. She was treated with topical steroids along with continuation of antitubercular therapy, and improved on this treatment.

Phlyctenular conjunctivitis is a type IV cellmediated hypersensitivity reaction to endogenous microbial proteins. It is more commonly reported from developing countries in the paediatric age group in association with pulmonary and lymph node tuberculosis. ${ }^{12}$ An association with intramedullary tuberculoma has not been reported in the existing literature.

A young woman being treated for spinal intramedullary tuberculomas (figure 1) developed phlyctenular conjunctivitis (figure 2A, B), which was asymptomatic, although its appearance was alarming for the patient and her family. Her neurological

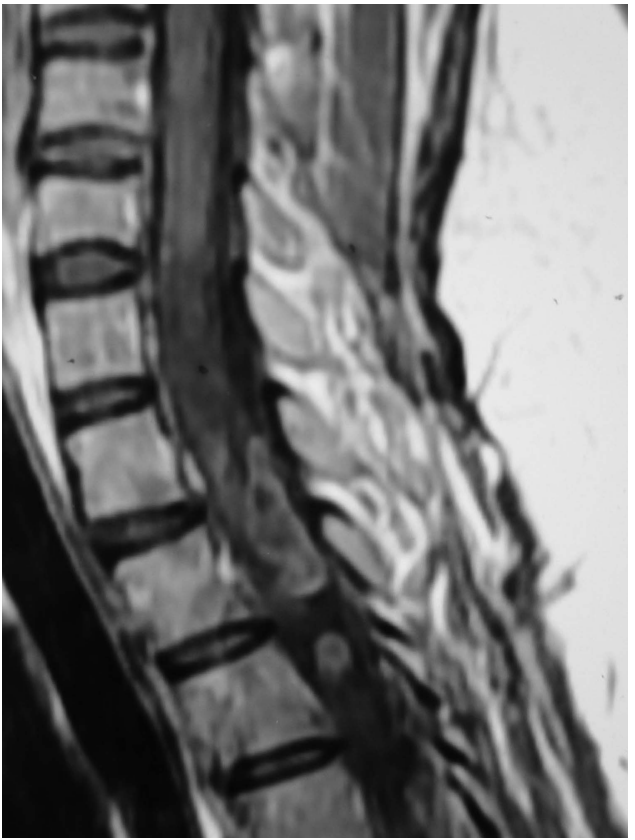

Figure 1 T1-weighted sagittal contrast MRI of the spinal cord depicting hyperintense irregularly enhancing intramedullary lesions at D2 and D4 vertebral level suggestive of tuberculomas.
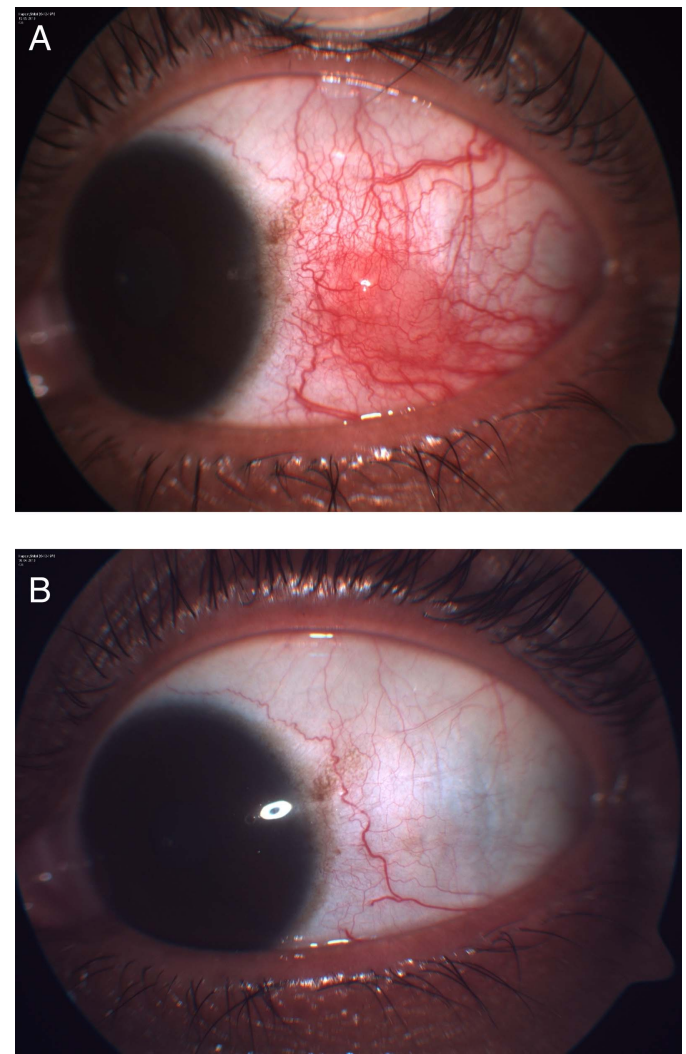

Figure 2 (A) Slit-lamp photograph of the left eye before treatment showing nodule near the limbus with surrounding hyperaemic and engorged conjunctival vessels suggestive of phlyctenular conjunctivitis.

(B) Slit-lamp photograph of the left eye after treatment depicts resolution.

examination was normal except for bilateral extensor plantars.

A timely diagnosis of this condition is important. Delay in diagnosis might lead to corneal ulceration, secondary infection and perforation. The treatment comprises topical steroids and antibiotics or antitubercular therapy in case of a tubercular aetiology.

\section{Learning points}

- Although usually described with cutaneous and lymph node tuberculosis, phlyctenular conjunctivitis can also be associated with central nervous system tuberculosis.

- A high index of suspicion is required for the diagnosis and timely treatment of this condition to prevent possible complications such as corneal ulcer and perforation.

- Recurrences are common in phlyctenular conjunctivitis and every episode should be treated. 
Competing interests None.

Patient consent Obtained.

Provenance and peer review Not commissioned; externally peer reviewed.

\section{REFERENCES}

1 Rohatgi J, Dhaliwal U. Phlyctenular eye disease: a reappraisal. Jpn J Ophthalmol 2000;44:146-50.

2 Kinsey HI. Phlyctenular conjunctivitis in relation to tuberculosis in children. Can Med Assoc J 1932;26:298-301.

Copyright 2014 BMJ Publishing Group. All rights reserved. For permission to reuse any of this content visit http://group.bmj.com/group/rights-licensing/permissions.

BMJ Case Report Fellows may re-use this article for personal use and teaching without any further permission.

Become a Fellow of BMJ Case Reports today and you can:

- Submit as many cases as you like

- Enjoy fast sympathetic peer review and rapid publication of accepted articles

- Access all the published articles

- Re-use any of the published material for personal use and teaching without further permission

For information on Institutional Fellowships contact consortiasales@bmjgroup.com

Visit casereports.bmj.com for more articles like this and to become a Fellow 